\title{
Evaluation of life quality of patients submitted to cataract surgery with implants of monofocal, bifocal and multifocal lenses
}

\author{
Avaliação da qualidade de vida em pacientes submetidos à cirurgia de \\ catarata, com implantes de lentes monofocais bifocais e multifocais
}

Beogival Wagner Lucas Santos ${ }^{1}$, José Eduardo Prata Cançado², Vauney Alves da Silva Ferraz², Mauro Campos ${ }^{3}$

\begin{abstract}
Purpose: Providing an objective and subjective evaluation of life quality and satisfaction level of the patients who underwent cataract surgery with implant of bifocal, multifocal and monofocal lenses. Methods: Bifocal lenses were implanted in 72 patients, aspheric multifocal lenses in 16 patients, apodized multifocal lenses in 20 patients and Monofocal lenses were implanted in 63 patients. The patients answered a 47 question questionnaire, whose results were evaluated and analyzed. Results: The level of satisfaction of the patients implanted with bifocal and multifocal lenses was significantly higher than of those with monofocal lenses (kruskal - Wallis test, $p<0.001$ followed by the Dunn test, $p<0.05$ ). As to the comparison of monofocal lenses with bifocal and multifocal lenses, the near vision without correction was considerably lower in patients with monofocal lenses $(Z$ test $p<0.001)$. The patients with monofocal lenses without correction presented a much lower capacity of reading newspapers or books and as far as manual work than the ones with bifocal and multifocal lenses $(Z$ test, $p<0.001)$. Conclusion: The result of this study shows that the patients who received the bifocal and multifocal lenses had a remarkable improvement in their visual acuity for the near vision, being pleased with their general vision without wearing glasses. This is because they were able to read books and newspapers, write checks, fill out forms, do sports, shave or put on make-up, hence having high quality of life without correction.
\end{abstract}

Keywords: Life quality; Intraocular lenses; Cataract extraction; Questionnaires

\section{RESUMO}

Objetivo: Fornecer uma avaliação objetiva e subjetiva da qualidade de vida e o nível de satisfação de pacientes que se submeteram à cirurgia de catarata, com implante de lentes bifocais, multifocais e monofocais. Métodos: Lentes bifocais foram implantadas em 72 pacientes; lentes multifocais asférica em 16 pacientes; lentes multifocais apodizada em 20 pacientes e lentes monofocais em 63 pacientes. Foi aplicado um questionário de 47 perguntas cujos resultados foram avaliados e analisados. Resultados: O nível de satisfação dos pacientes implantados com lentes bifocais e multifocais foi significantemente mais alto do que aqueles com lentes monofocais (teste Kruskal-Wallis $\mathrm{p}<0,01$, seguido do teste Dunn, $\mathrm{p}<0,05$ ). Quanto à comparação de lentes monofocais com lentes bifocais e multifocais, a visão para perto sem correção foi consideravelmente mais baixa em pacientes com lentes monofocais (teste $\mathrm{Z}, \mathrm{p}<0,001)$. Os pacientes com lentes monofocais sem correção apresentaram uma menor capacidade de ler jornais ou livros e no que diz respeito a trabalhos manuais do que aqueles com lentes bifocais e multifocais (teste $Z, p<0,001$ ). Conclusão: Os resultados deste estudo mostram que os pacientes que receberam as lentes bifocais e multifocais tiveram uma melhora notável em sua acuidade visual para perto, estando satisfeitos com sua visão geral, sem óculos. A satisfação foi atribuída ao fato de conseguirem ler livros e jornais, preencher cheques, preencher formulários, praticar esportes, se barbear ou se maquiar sem correção.

Descritores: Qualidade de vida; Lentes intraoculares; Extração de catarata; Questionários

\footnotetext{
${ }^{1}$ Federal University of São Paulo, São Paulo/SP, Brazil.

${ }^{2}$ Eye Hospital (CIOMS), Campo Grande/MS, Brazil.

${ }^{3}$ Federal University of São Paulo, São Paulo/SP, Brazil.
}

The authors declare no conflict of interest.

Received for publication 22/5/2013 - Accepetd for publication 02/12/2013 


\section{INTRODUCTION}

$\mathbf{T}$ The eye typically undergoes two physiological phenomena during its aging process: loss of ability to focus at varying distances (presbyopia) and gradual opacification of the lens in most patients (cataract). Impaired accommodation is usually compensated with bifocal or multifocal glasses, while cataract is usually treated surgically by removing the lens and implanting an intraocular lens (IOL). Despite advances in cataract surgery in many parts of the world, cataract is the leading cause of surgically-preventable blindness. In 2002 cataract was responsible for an estimated 37 million cases of blindness among 161 million visually-impaired individuals. Cataract is believed to account for $48 \%$ of all visual impairments ${ }^{(1)}$. Its worldwide distribution is not uniform. It is estimated that $10 \%$ of the population over 50 years of age has cataract, a prevalence that increases to $50 \%$ in persons aged $65-74$ years and $75 \%$ in persons older than 75 years $^{(2)}$.

Cataract surgery improved with the advent of the phacoemulsifier to fragment the crystalline, a technique that evolved for 20 years before spreading in the late 80 's. It leads to rapid visual recovery and more controlled healing, with better control over surgical time ${ }^{(3)}$. Successive generations of monofocal IOLs have also provided a good level of satisfaction among both surgeons and patients. These IOLs are still the most commonly used to replace the crystalline lens in cataract surgery. However, monofocal IOLs have limitations as they only provide good visual acuity in a single focal plane, either far or near. Patients usually need glasses to perform activities that require a better visual acuity in the focal plane not corrected by the chosen $\operatorname{IOL}^{(4,5)}$. Multifocal IOLs provide better visual performance than monofocal IOLs, as they improve both near and far visual acuity with little or no correction. Although some patients with bifocal or multifocal IOLs require correction for extremely detailed near vision, it is usually not greater than 1.50 dioptres $^{(4)}$. However, clinical and laboratory studies have shown a decrease in image quality and contrast sensitivity and a greater incidence of halos and glare at night with multifocal IOLs ${ }^{(6,7)}$.

In 1862 the Dutch ophthalmologist Snellen was the first to develop a visual chart based on the finding that most persons with normal visual acuity had a visual angle of up to one minute for black objects on a white background. He used upper-case letters of the alphabet, which have certain angles at specific distances. The process of identifying letters is influenced by experience, familiarity and psychological factors, which can lead to incorrect interpretation depending on a letter's configuration. Despite these factors, it is still the preferred clinical test ${ }^{(8)}$. It has been noted that even patients whose vision is not ideal according to Snellen's chart report being satisfied with the outcome of cataract surgery. This is why it is important to examine the quality of life and personal satisfaction of patients through questionnaires assessing their ability to perform daily tasks with or without correction, such as reading traffic signs; making handicrafts (sewing and embroidering); writing cheques or filling in forms; playing bingo, dominoes, or cards; playing sports; cooking; watching television; driving at day and night; and shaving or applying makeup. This is a more reliable way to know whether patients are satisfied with their visual outcome after cataract surgery.

\section{Methods}

The study included 171 patients from the CIOMS (Integrated Ophthalmic Centre of Mato Grosso do Sul) Eye Hospital. A questionnaire (Appendix 1) with 47 questions assessing patient satisfaction, the need for eye glasses, and quality of life was administered to all patients by the same examiner. The questionnaire was developed by combining 3 questionnaires that had been previously validated in a pilot project $^{(5,7,9)}$ on 72 patients (mean age, 69 years) submitted to cataract surgery with implantation of biconvex refractive bifocal lenses (Array SA40N, AMO Inc.) in both eyes. This group was prospectively compared with: 16 patients (mean age, 60 years) implanted with biconvex multifocal aspheric diffractive IOLs (Tecnis ZM900, AMO inc.); 20 patients (mean age, 65 years) implanted with apodised multifocal diffractiverefractive IOLs (Restor SA60D3, Alcon Inc.); and 63 patients (mean age, 66 years) implanted with biconvex monofocal spherical IOLs (Clariflex SI40NB, AMO inc.).

All patients underwent surgery in both eyes. All patients provided their Free and Informed Consent, and the study was approved by the Research Ethics Committee (REC) of the Federal University of São Paulo. The questionnaire was applied approximately 2 years (22-26 months) after surgery due to the need for neural adaptation to bifocal or multifocal IOLs ${ }^{(10)}$.

The inclusion criteria for bifocal or multifocal IOLs were patients submitted phakectomy without surgical complications, a centred IOL, and clear media. The exclusion criteria were: (1) patients with preoperative eye conditions that might compromise visual acuity, such as diabetes mellitus, uveitis, glaucoma, previous eye surgery, and maculopathy; and (2) patients with intra- or postoperative complications (posterior capsule rupture, discontinuous capsulorhexis, uveitis, endophthalmitis), preoperative corneal topographic astigmatism greater than 1.00 $\mathrm{D}$ cyl, IOL dislocation (when possible, the IOL was recentered). (3) Patients who did not adhere to postoperative treatment or did not attend follow-up visits.

\section{Characteristics of the IOLs}

The Clariflex biconvex monofocal spherical IOL is a 3piece IOL with a $6.0-\mathrm{mm}$ silicone optical zone and C-shaped polyvinylidene haptics with an angulation of 10 degrees.

The Array SA40N biconvex bifocal refractive IOL has progressive bifocal areas with 5 concentric refractive zones for near and far vision: zones 1, 3 and 5 for far vision and zones 2 and 4 for near vision; its adding power is $3.50 \mathrm{D}$; it is a 3-piece IOL with a silicone optical zone and polyvinylidene haptics.

The Tecnis ZM900 biconvex aspheric diffractive IOL is a multifocal silicone IOL implanted in the posterior chamber. It is a 3-piece IOL with a biconvex optic and flexible haptics. The haptics are made of polyvinylidene fluoride and are C-shaped, with an anterior angulation of 6 degrees. Its total diameter is $13.0 \mathrm{~mm}$, with a $6.0-\mathrm{mm}$ optical zone. It has a prolate anterior surface and a diffractive posterior surface. The diffraction pattern consists of 32 concentric rings with steps of approximately 0.25 $\mathrm{mm}$. The central zone is $1.0-\mathrm{mm}$ wide. The anterior surface has a spherical aberration of $-0.27 \mathrm{~mm}$ for a $6.0-\mathrm{mm}$ pupil. Its adding power is $+3.75 \mathrm{D}$ for near vision. Its refractive index is 1.46 at $37^{\circ} \mathrm{C}$, with a constant of $119.8^{(11)}$.

The Restor SN60D3 is an apodised multifocal refractivediffractive IOL. It is a single-piece IOL made of hydrophobic 
Annex A1

Questionnaire to assess patients implanted bilaterally with bifocal or multifocal IOLs versus monofocal IOLs.

Name:

Age:

Sex: female ( ) male ( )

Occupation:

1) How often do you need glasses for far vision?

( )

2) How often do you need glasses for near vision?

( )

(1) Never (2) Infrequently (3) Half of the time (4) Frequently (5) Always

3) How satisfied are you with your overall vision?

4) How satisfied are you with your vision during the day?

( )

5) How satisfied are you with your vision during the night?

( )

()

6) How satisfied are you with your overall vision without glasses?

( )

7) How satisfied are you with your overall vision with glasses?

()

8) How satisfied are you with your far vision with glasses?

()

9) How satisfied are you with your far vision without glasses?

( )

10) How satisfied are you with your near vision with glasses?

11) How satisfied are you with your near vision without glasses?

( )

(1) completely unsatisfied (2) unsatisfied (3) indifferent (4) satisfied (5) very satisfied

12) Do you feel discomfort due to halos, rings or glare around light sources?

(1) Never (2) Infrequently (3) Half of the time (4) Frequently (5) Always

13) Have you lost the ability to perform some activity after surgery?

14) If yes, what?

15) Were there any complications during surgery?

16) If yes, what?

17) Can you read small print such as medicine information leaflets, phone books or food labels (without glasses)?

18) Can you read small print such as medicine information leaflets, phone books or food labels (with glasses)? ( )

19) Can you read a newspaper or book (without glasses)?

( )

20) Can you read a newspaper or book (with glasses)?

( )

21) Can you read a book with large print or the numbers in a telephone pad (without glasses)?

( )

22) Can you read a book with large print or the numbers in a telephone pad (with glasses)?

( )

23) Can you recognise people near you (without glasses)?

( )

24) Can you recognise people near you (with glasses)?

( )

25) Can you see steps or stairs (without glasses)?

( )

26) Can you see steps or stairs (with glasses)?

27) Can you read traffic signs (without glasses)?

( )

28) Can you read traffic signs (with glasses)?

( )

29) Can you make handicrafts such as sewing and embroidering (without glasses)?

( )

30) Can you make handicrafts such as sewing and embroidering (with glasses)?

31) Can you write cheques or fill in forms (without glasses)?

32) Can you write cheques or fill in forms (with glasses)?

33) Can you play bingo, domino or cards (without glasses)?

( )

34) Can you play bingo, domino or cards (with glasses)?

35) Can you play sports such as bowling, handball, tennis or golf (without glasses)?

( )

36) Can you play sports such as bowling, handball, tennis or golf (with glasses)?

( )

37) Can you cook (without glasses)?

38) Can you cook (with glasses)?

39) Can you watch TV (without glasses)?

40) Can you watch TV (with glasses)?

41) Can you drive during the day (without glasses)?

( )

42) Can you drive during the day (with glasses)?

( )

()

43) Can you drive during the night (without glasses)?

44) Can you drive during the night (with glasses)?

45) Can you shave or apply makeup (without glasses)?

( )

( )

46) Can you shave or apply makeup (with glasses)?

()

( )

( )

( )

( )

47) Did you pass your driver's licence tests?
(1) yes
(2) no 
Table 1

\section{Patient satisfaction with regard to overall vision, day and night vision, and uncorrected near and far vision among subjects implanted with different types of IOLs.}

\begin{tabular}{|c|c|c|c|c|c|}
\hline Variable & Monofocal & Bifocal & Aspheric & Apodized & p-value \\
\hline $\begin{array}{l}\text { Satisfaction } \\
\text { with overall } \\
\text { day vision }\end{array}$ & $\begin{array}{l}\text { Satisfied } \pm \\
\text { (unsatisfied and } \\
\text { very satisfied) }\end{array}$ & $\begin{array}{l}\text { Very satisfied } \pm \\
\text { (Unsatisfied and } \\
\text { very satisfied) }\end{array}$ & $\begin{array}{l}\text { Very satisfied } \pm \\
\text { (Very satisfied and } \\
\text { very satisfied) }\end{array}$ & $\begin{array}{l}\text { Very satisfied } \pm \\
\text { (Very satisfied and } \\
\text { very satisfied) }\end{array}$ & $\begin{array}{l}\mathrm{p}<0,001 \text { Technis } \\
\text { and } \\
\text { Restor }>\text { Monofocal }\end{array}$ \\
\hline $\begin{array}{l}\text { Satisfaction } \\
\text { with overall } \\
\text { night vision }\end{array}$ & $\begin{array}{l}\text { Satisfied } \pm \\
\text { (completely } \\
\text { unsatisfied and } \\
\text { very satisfied) }\end{array}$ & $\begin{array}{l}\text { Very satisfied } \pm \\
\text { (Unsatisfied and } \\
\text { very satisfied) }\end{array}$ & $\begin{array}{l}\text { Very satisfied } \pm \\
\text { (Very satisfied and } \\
\text { very satisfied) }\end{array}$ & $\begin{array}{l}\text { Very satisfied } \pm \\
\text { (Very satisfied and } \\
\text { very satisfied) }\end{array}$ & $\begin{array}{l}\mathrm{p}<0,001 \text { Array } \\
\text { SA40N, Technis and } \\
\text { Restor }>\text { Monofocal }\end{array}$ \\
\hline $\begin{array}{l}\text { Satisfaction with } \\
\text { near vision } \\
\text { without glasses }\end{array}$ & $\begin{array}{l}\text { Unsatisfied } \pm \\
\text { (completely } \\
\text { unsatisfied } \\
\text { and satisfied) }\end{array}$ & $\begin{array}{l}\text { Satisfied } \pm \\
\text { (Completely } \\
\text { unsatisfied and } \\
\text { very satisfied) }\end{array}$ & $\begin{array}{l}\text { Very satisfied } \pm \\
\text { (Satisfied and } \\
\text { very satisfied) }\end{array}$ & $\begin{array}{l}\text { Very satisfied } \pm \\
\text { (Satisfied and } \\
\text { very satisfied) }\end{array}$ & $\begin{array}{l}\mathrm{p}<0,001 \text { Array } \\
\text { SA40N, Technis and } \\
\text { Restor }>\text { Monofocal }\end{array}$ \\
\hline
\end{tabular}

Results are presented as median \pm minimum and maximum. Comparisons were done using the Kruskal-Wallis test followed by Dunn's posttest.

acrylic with a $6.0 \mathrm{~mm}$ optic part and a total diameter of $13.0 \mathrm{~mm}$. It has a yellow filter to block light in the blue spectrum. Its multifocal diffractive rings are in the centre and occupy an area with a $3.6 \mathrm{~mm}$ diameter. It is a hybrid apodised multifocal refractive-diffractive lens with an adding power of $+4.00 \mathrm{D}$ in the lens plane (3.2 D in the corneal plane). This lens has a set of circular zones to split the light into two focal points (40\% for far vision, $40 \%$ for near vision, and the remainder is lost in diffraction). The focus for far vision is projected on the foveola, and the focus for near vision is projected approximately $1.0 \mathrm{~mm}$ before the foveola ${ }^{(11)}$.

\section{Statistical Methods}

The different types of IOLs were compared regarding patient satisfaction with overall vision, day vision, and uncorrected near and far vision. This was done using the Kruskal-Wallis test followed by Dunn's test. Other results are presented as descriptive statistics or in tables.

\section{Results}

Table 1 shows the results for the level of satisfaction with overall vision, day and night vision, and uncorrected near and far vision among patients implanted with different IOLs. The level of satisfaction of patients implanted with bifocal and multifocal IOLs was significantly higher than for monofocal IOLs (Kruskal-
Wallis, $\mathrm{p}<0.001$; Dunn's post-test, $\mathrm{p}<0.05)$. There was no difference between bifocal and multifocal IOLs for the level of satisfaction with overall vision, day and night vision, and uncorrected near and far vision (Dunn's post-test, $\mathrm{p}>0.05$ ).

Among patients implanted with monofocal IOLs, 58.7\% were male and $41.3 \%$ were female; for bifocal IOLs, $43.1 \%$ were male and $56.9 \%$ were female; for multifocal IOLs, $50 \%$ were male and $50 \%$ were female, with an even distribution between sexes (86 males and 85 females).

Figure 1 shows a significant association between the type of IOL and the ability to read small print (J2 or better) postoperatively (chi-squared test, $\mathrm{p}<0.001$ ). The percentage of patients with monofocal IOLs who could read small print was significantly lower than for bifocal and multifocal IOLs (Z-test, $\mathrm{p}<0.001)$. Furthermore, the percentage of patients with bifocal IOLs who could read small print was significantly lower than for aspheric multifocal IOLs (Z-test, $\mathrm{p}=0.002)$ and for apodised multifocal IOLs (Z-test, $\mathrm{p}<0.001)$. There was no significant difference between aspheric and apodised IOLs in the ability to read small print ( $Z$-test, $\mathrm{p}>0.05$ ). Table 2 shows a significant association between the type of IOL and the ability to read a book or a newspaper (chi-squared test, $\mathrm{p}<0.001$ ). The percentage of patients with monofocal IOLs who could read a newspaper or a book without glasses was significantly lower than for bifocal and multifocal IOLs (Z-test, $\mathrm{p}<0.001)$. There was no difference between bifocal and multifocal IOLs for the ability to read newspapers and books without glasses $(p>0.05)$. Finally, there 
Tabela 2

Assessing patients for the ability to perform the activities they performed before surgery.

IOL

Lost the ability to perform some activity
Yes
No
Able to read small print without glasse
Yes
No
Able to read small print with glasses
Yes
No
Does not wear glasses

Able to read a newspaper or book without glasses

Yes

No

Able to make handicrafts without glasses

Yes

No

Able to make handicrafts with glasses

Yes

No

Does not wear glasses

Able to write cheques or fill in forms without glasses

Yes

No

Able to write cheques or fill in forms with glasses

Yes

No

Does not wear glasses

Able to drive during the day without glasses

Yes

No

Does not drive

Able to drive during the night without glasses

Yes

No

Does not drive

Managed to pass driver's licence tests

Yes

No

Not tested yet

Does not drive

\section{Monofocal}

Bifocal Aspheric Apodized

$0,0 \quad(\mathrm{n}=0)$

$100,0(n=63)$

$4,8(n=3)$

$95,2(\mathrm{n}=60)$

$100,0(n=63)$

$0,0(\mathrm{n}=0)$

$0,0(\mathrm{n}=0)$

$1,6(n=1)$

$98,4(\mathrm{n}=62)$

$3,2(\mathrm{n}=2)$

$96,8(n=61)$

$66,7(n=42)$

$33,3 \quad(n=21)$

$0,0 \quad(n=0)$

$33,3(\mathrm{n}=21)$

66,7 $(\mathrm{n}=42)$

$98,4(\mathrm{n}=62)$

$1,6(n=1)$

$0,0(\mathrm{n}=0)$

$100,0 \quad(\mathrm{n}=63)$

$0,0(\mathrm{n}=0)$

$0,0(\mathrm{n}=0)$

$100,0 \quad(n=63)$

$0,0(\mathrm{n}=0)$

$0,0 \quad(n=0)$

47,6 $(\mathrm{n}=30)$

$7,9(\mathrm{n}=5)$

44,4 $(\mathrm{n}=28)$

$0,0(\mathrm{n}=0)$ $6,9(\mathrm{n}=5)$

$93,1(n=67)$

$55,6(\mathrm{n}=40)$

$44,5(n=32)$

$47,2(\mathrm{n}=34)$

$5,6(\mathrm{n}=4)$

47,2 $(\mathrm{n}=34)$

$83,3(\mathrm{n}=60)$

$16,7(\mathrm{n}=12)$

$80,6(n=58)$

$19,5(n=14)$

48,6 (n=35)

$2,8(\mathrm{n}=2)$

$48,6(n=35)$

93,1 $(\mathrm{n}=67)$

$7,0(n=5)$

$50,0 \quad(\mathrm{n}=36)$

$0,0(\mathrm{n}=0)$

$50,0 \quad(n=36)$

68,1 (n=49)

$0,0 \quad(\mathrm{n}=0)$

$31,9(n=23)$

$66,7(\mathrm{n}=48)$

$1,4(\mathrm{n}=1)$

$31,9(n=23)$

23,6 $(\mathrm{n}=17)$

$1,4(\mathrm{n}=1)$

47,2 (n=34)

$27,8(\mathrm{n}=20)$

$$
0,0(\mathrm{n}=0)
$$

100,0 $(\mathrm{n}=16)$

$0,0 \quad(\mathrm{n}=0)$

$100,0(\mathrm{n}=16)$

$0,0(n=0)$

$100,0 \quad(n=20)$

100,0 $(\mathrm{n}=16)$

$0,0 \quad(\mathrm{n}=0)$

$0,0(n=0)$

100,0 $(\mathrm{n}=20)$

$0,0(\mathrm{n}=0)$

$0,0 \quad(n=0)$

100,0 $(\mathrm{n}=16)$

100,0 $(\mathrm{n}=20)$

$0,0(\mathrm{n}=0)$

$0,0(n=0)$

$100,0(\mathrm{n}=16)$

100,0 $(\mathrm{n}=20)$

$0,0(n=0)$

$0,0(n=0)$

$100,0 \quad(n=16)$

$100,0(\mathrm{n}=20)$

$0,0 \quad(\mathrm{n}=0)$

$0,0(\mathrm{n}=0)$

$0,0 \quad(\mathrm{n}=0)$

$0,0 \quad(n=0)$

$100,0(n=16)$

100,0 $(\mathrm{n}=20)$

$0,0(n=0)$

$0,0(\mathrm{n}=0)$

$100,0(\mathrm{n}=16)$

$0,0(\mathrm{n}=0)$

100,0 $(\mathrm{n}=20)$

$0,0(\mathrm{n}=0)$

$0,0(\mathrm{n}=0)$

$0,0(\mathrm{n}=0)$

$100,0(\mathrm{n}=16)$

100,0 $(\mathrm{n}=20)$

$0,0(\mathrm{n}=0)$

$0,0(\mathrm{n}=0)$

$0,0 \quad(n=0)$

$0,0(\mathrm{n}=0)$

$100,0 \quad(n=16)$

95,0 (n=19)

$0,0 \quad(n=0)$

$5,0(\mathrm{n}=1)$

$0,0(\mathrm{n}=0)$

$0,0(\mathrm{n}=0)$

$25,0 \quad(n=4)$

$10,0(\mathrm{n}=2)$

$6,3(n=1)$

68,8 $(\mathrm{n}=11)$

$0,0(\mathrm{n}=0)$

90,0 $(\mathrm{n}=18)$

$0,0(\mathrm{n}=0)$

$0,0(n=0)$

Results are shown as percentage (absolute frequency).

was a significant association between the type of IOL and the ability to make handicrafts such as sewing or embroidering (chisquared test, $\mathrm{p}<0.001)$. The percentage of patients with monofocal IOLs who could do handicrafts without glasses was significantly lower than for bifocal and multifocal lenses (Z-test, $\mathrm{p}<0.001$ ).

\section{Discussion}

All patients in this study had presbyopia, and surgery was indicated based on rigorous criteria. Patients submitted to surgery had bilateral cataract, a regular topographic image of the cornea, and astigmatism under $1 \mathrm{D}$ cyl. Previous studies reported a high degree of satisfaction among patients implanted with bifocal and multifocal IOLs ${ }^{(12)}$. In this study $80.9 \%$ of patients with monofocal IOLs, $86.1 \%$ of patients with bifocal IOLs, and $100 \%$ of patients with apodised aspheric IOLs reported being satisfied or very satisfied with their overall day vision without glasses. These results are also in agreement with de Vrieset et al. Other authors ${ }^{(14)}$ reported that patients with bifocal and multifocal IOLs had less visual problems than patients with monofocal IOLs, either during the day or night and without glasses, although the difference was not statistically significant when patients wore glasses. In this study, $73 \%$ of patients with monofocal IOLs, $87.5 \%$ with bifocal IOLs, $100 \%$ with aspheric IOLs, and $100 \%$ with apodised IOLs reported being satisfied or very satisfied with their night vision 


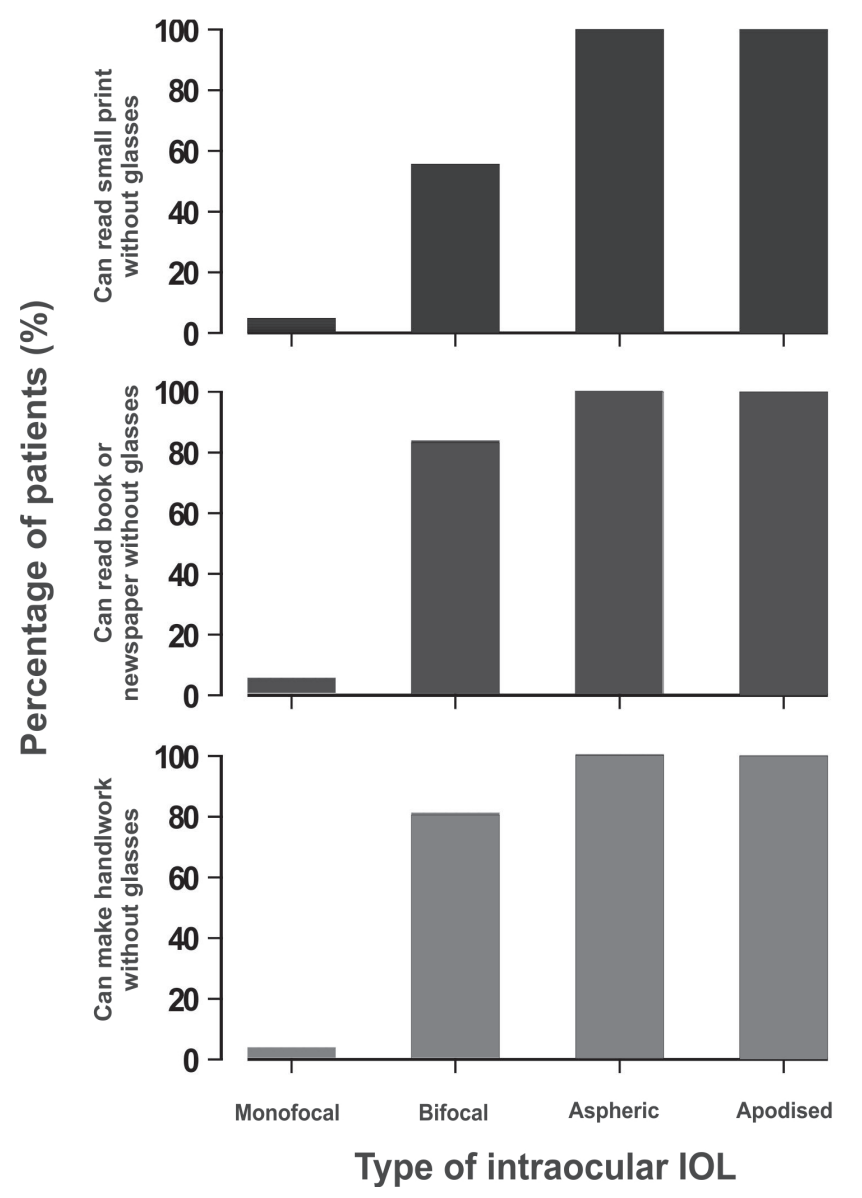

Figure 1: Percentage of patients implanted with different IOLs who could read small print, read a book or a newspaper, and make handicrafts without glasses. Columns represent percent values.

without glasses. Also, $68.2 \%$ of patients with monofocal IOLs, $88.9 \%$ with bifocal IOLs, $100 \%$ with aspheric IOLs, and $100 \%$ with apodised IOLs reported being satisfied or very satisfied with their overall vision without glasses. Furthermore, 3.2\% of patients with monofocal IOLs, $84.7 \%$ with bifocal IOLs, $100 \%$ with aspheric IOLs, and $100 \%$ with apodised IOLs reported being satisfied or very satisfied with their near vision without glasses. This is in agreement with a previous study ${ }^{(15)}$ where $75 \%$ of patients in the multifocal group had a $\mathrm{J} 1$ vision versus $10 \%$ in the monofocal group, while $95 \%$ of patients in the multifocal group achieved a visual acuity of $\mathrm{J} 2$ or better. Other authors ${ }^{(16)}$ have shown that multifocal IOLs provide better depth of focus and high patient satisfaction, facilitating tasks that require intermediate and near vision. It has also been reported that $23.8 \%$ of patients with monofocal IOLs, $55.5 \%$ with bifocal IOLs, $56.3 \%$ with aspheric IOLs, and $40 \%$ with apodised IOLs were bothered by halos, rings or reflexes around light foci. Other authors $^{(17,18)}$ compared multifocal refractive IOLs with monofocal IOLs and found statistically-significant differences in visual symptoms such as halos, glare and blurred far vision. Patients reported significant improvements in these symptoms by the $6^{\text {th }}$ postoperative month, probably due to neural adaptation ${ }^{(10)}$. Objective and subjective assessments showed that patients with bifocal and multifocal IOLs were more independent from glasses, with a better visual outcome and higher patient satisfaction for far, intermediate and near vision ${ }^{(9,12,13,16,19)}$. Bifocal IOLs can be a cost-effective alternative for patients in poor financial condition as they reduce the need for glasses after cataract surgery ${ }^{(5)}$. Note that it would be appropriate to apply the questionnaire more than once and at different dates. Our study was a case series, and not a randomised clinical trial. It is recommended to assess the mental health of subjects to be included in a study and to correlate the questionnaire results with objective tests of visual acuity.

\section{Conclusion}

In this study, the subjective evaluation of patients with bifocal and multifocal IOLs showed that the vast majority of subjects reported being satisfied with their overall vision, as they were able to read newspapers or books, recognise people, read traffic signs, write cheques and fill in forms, play sports, cook, watch TV, and shave or apply makeup without glasses, thus providing a good quality of life. Similar results were found for patients with monofocal IOLs but in a lesser degree, as they required glasses for near vision. Thus, multifocal IOLs were shown to be a predictable, reproducible and safe alternative for correcting near and far refractive errors, providing better quality of life and independence from glasses and enabling patients to perform daily tasks.

\section{RefERenCES}

1. Resnikoff G, et al. Global data on Visual impairment in the year 2002, Bulletin of the World Health Organization. 2004.

2. Conselho Brasileiro de Oftalmologia. Projeto e diretrizes. 2003. São Paulo: CBO: 2003.

3. Mckellar MJ,Elder MJ.The early complications of cataract surgery: is routine review of patients 1 week after cataract extraction necessary. Ophalmology. 2001; 108(5): 930-5.

4. Vaquero M,Encinas JL, Jimenez F. Visual function with monofocal versus multifocal IOLs. J Cataract Refract Surgery. 1996; 22: 1222-5.

5. Sedgewick JH, Orillac R, Link C. Array multifocal intraocular lens in a charity hospital training program. J Cataract Refract Surg 2002 Jul; 28 (7) :1205-10.

6. Rommel JG. The Array multifocal intraocular lens: a new horizon. Bull Soc Belge Ophthalmol. 2001; 280: 45-49.

7. Kaushik S, Kamlesh. A clinical evaluation an aspheric multifocal intraocular lens and its implications for the developing world. Ophthalmic Surgery and Lasers. 2002 Jul-Aug; 33(4): 298-303.

8. Duane T. Optics of intra-ocular lenses. Clinical Ophthalmology. Philadelphia: Harper \& Row, 1987.

9. Brydon KW,Tokarewicz AC, Nichols BD. Amo Array Multifocal Lens Versus Monofocal Correction in Cataract Surgery. J Cataract Refract Surg. 2000 Jan; 26(1): 96-100.

10. Lubinski W, Serafin GJ, Jodko-k P, Karczewicz D. Cataract surgery with bilateral multifocal rezoom IOL implantation- comparison of 3 and 12 month follow-up. Klin Oczna. 2009; 111 (1012): $327-31$.

11. Castillo-Gómez A, Carmona-González D, Martínez-de-la-Casa JM, Palomino-Bautista C, Garcia-Feijoo J. Evaluation of image quality after implantation of 2 diffractive multifocal intraocular lens models. J Cataract Refract Surg. 2009; 35: 1244-1250.

12. Cochener B, Fernández-Vega L, Alfonso JF, Maurel F, Meunier J, Berdeaux G. Spectacle independence and subjective satisfaction of ReSTOR multifocal intraocular lens after cataract or presbiopia surgery in Two European Countries. Clin Ophthalmol. 2010 Marc; $4: 81-9$ 
13. de Vries NE, Webers CA, Micó-R M, Tahzib NG, Cheng YY, de Brabander J, et al. Long-term follow-up of a multifocal apodized diffractive intraocular lens after Cataract Surgery. J Cataract Refract Surg. 2008, Sep; 34 (9):1476-82.

14. Javitt J C, Steinert R F. Cataract extraction with multifocal intraocular lens implantation: A multifocal Clinical Trial Evaluating, Functional and Quality-of-life outcomes. Ophthalmology. 2000, 107(11) 2040-8.

15. Akaishi L, Araújo AGR, Santos RCN, Santos PM. Acuidade visual em implantes bilaterais de lentes intraoculares monofocais e multifocais. Arq Bras Oftalmol. 2003, 66: 199-205

16. Cillino S, Casuccio A, Di Pace F, Morreale R, Pillitteri F, Cillino G, et al. One-year outcomes with new-generation multifocal intraocular lens. Ophtalmology. 2008 Sep; 115(9): 1508-16.

17. Steinert RF,Aker BL, trentacost DJ, Smith PJ,Tarantino N.A prospective comparative study of the amo array zonal-progressive multifocal silicone intraocular lens and a monofocal intraocular lens. Ophthalmology. 1999; 106 (7):1243-55.
18. Hida WT, Motta AF, Kara-José Junior N, Alves E, Tadeu M, Nakano CT. Comparação dos Resultados do OPD-Scan e performance visual das lentes intraoculares monofocal e multifocal. Arq Bras Oftalmol. 2009 Jul-Aug; 72 (4): 526-32.

19. Salera CM, Souza SE, Guimarães MR, Campolina RB, Guimarães RQ. Resultados do implante bilateral de lente intraocular multifocal SA40N no Hospital de Olhos de Minas Gerais. Arq Bras Oftalmol. 2005; 68(1): 117-21.

\section{Corresponding author:}

Rua Casemiro de Abreu, 350 - Jardim São Bento Campo Grande (MS), Brazil, CEP: 79004-190

Tel: +5567 30285025 ;

E-mail: beogival@hotmail.com 